\title{
Correlation between virulence markers of Helicobacter pylori in the oral cavity and gastric biopsies
}

\author{
Myriam Lucrecia MEDINA ${ }^{1}$, Marcelo Gabriel MEDINA² and Luis Antonio MERINO ${ }^{3}$
}

Received 13/11/2016 Accepted 27/3/2017

ABSTRACT - Background - The clinical outcome of Helicobacter pylori infection has been associated with virulence factors. The presence of these factors is useful as molecular markers in the identification of the high risk for developing severe gastric pathologies. Objective - To correlate the presence of virulence markers $c a g A$ and $b a b 2 A$ of $H$. pylori in oral and gastric biopsy samples. Methods - An observational, prospective, descriptive, and cross-sectional study was carried out between September 2011 and September 2012. Patients suffering dyspepsia with indication for upper gastrointestinal video endoscopy who attended the Gastroenterology Service of the Hospital Dr. Julio C. Perrando were included. Epidemiological investigation was completed. To detect the bacteria and their virulence genes, samples of saliva, dental plaque and gastric biopsy were taken and processed by PCR. Results - Sixty-one patients were selected for this study (30 women and 31 men). H. pylori was detected in 31 gastric biopsies and 31 oral samples. Significant difference between oral and gastric samples was found in $\operatorname{cag} A$ genotype. Agreement between oral and gastric genotypes was found in $38.7 \%$ of samples from the same patient. Conclusion - This study is the first in provide information about the genotypes of the Argentinean Northeast H. pylori strains. Despite the high prevalence of $H$. pylori infection, the most of patients had less virulent genotypes in oral cavity and gastric tissue. The cagAlbabA2 combination was not frequent in the samples studied. There was not a statistical correlation between the virulence genes and gastroduodenal or oral diseases. Although in some patients the same genotype was found both in oral and gastric samples, it cannot be ensure that they corresponding to the same strain because a DNA sequencing was not performed.

HEADINGS - Helicobacter pylori, genetics. Helicobacter infections, diagnosis. Gastric mucosa, microbiology. Saliva, microbiology.

\section{INTRODUCTION}

At least half the world's population is infected by Helicobacter pylori, making it the most widespread infection in the world. Actual infection rates vary from nation to nation, the people in under developed countries has much higher infection rates than the developed countries ${ }^{(20)}$.

The clinical course of $H$. pylori infection is highly variable depending on bacterial and host (genetic and immune) factors ${ }^{(9)}$.

It has been established that some genes differentially expressed between strains could be used as virulence markers in H. pylori $i^{(7)}$.

All identified H. pylori strains possess the vacA gene which codifies for the VacA toxin; this toxin has a vast array of functions that span induction of apoptosis to modulation of the immune system $^{(13,26)}$.

Additionally, disruption of epithelial cell polarity by CagA protein, codified by the $\operatorname{cag} A$ gene, is thought to be an indispensable role in the development of gastric carcinoma ${ }^{(23)}$ and the strains $\operatorname{cag} A+$ are more associated with severe inflammation that those $\operatorname{cag} A$ - strains $^{(15)}$.
The first identified and probably the best characterized adhesin of $H$. pylori is a $78 \mathrm{KDa}$ protein termed BabA (blood group antigen binding adhesion) $)^{(14)}$. Carriage of the babA2+ strains was associated with more intense chronic inflammation, and presence of glandular gastric atrophy and intestinal metaplasia in the gastric antrum ${ }^{(40)}$.

The presence of $H$. pylori in the oral cavity of patients suffering digestive pathologies has been published and it is more frequent in those patients harboring a periodontal disease $\mathrm{e}^{(19,35)}$.

Some authors indicate that gastric reflux is not the only route by which $H$. pylori reaches the mouth and its detection and the genotyping in mouth and in stomach are complementary tests to understand some epidemiological issues ${ }^{(21)}$.

Therefore, any information about cag Aand babA2genotypes prevalence among different $H$. pylori-infected clinical groups in the country can help public health authorities to plan preventive policies to reduce the prevalence of diseases associated with $H$. pylori infection $^{(32)}$.

The aim of this work was to detect and correlate the virulence markers $c a g A$ and babaA2 of $H$. pylori in gastric biopsies and oral cavity samples.

Declared conflict of interest of all authors: none

Disclosure of funding: The present work had the financial support of the "Alberto J. Roemmers" Foundation and the National Agency for Scientific and Technological Promotion (Ministry of Science, Technology and Productive Innovation, Argentina) through the grant PICTO-UNNE 2010.

${ }^{1}$ Unidad de Investigación, Hospital Pediátrico Dr. Avelino Castelán, Resistencia, Argentina. ${ }^{2}$ Area de Medicina Tropical, Instituto de Medicina Regional, Universidad Nacional del Nordeste, Resistencia, Argentina. ${ }^{3}$ Area de Bacteriología, Instituto de Medicina Regional, Universidad Nacional del Nordeste, Resistencia, Argentina.

Correspondence: Luis A. Merino. Chaco, 1163, 6 B - Corrientes, Argentina. E-mail: luisantoniomerino@gmail.com 


\section{METHODS}

An observational, descriptive, prospective, and cross-sectional study was carried out between September 2010 and September 2012. Patients with dyspeptic symptomatology and indication for upper gastrointestinal video endoscopy (UGVE) were studied.

We included all patients of both sexes, aged between 18 and 80 years attended to the Service of Gastroenterology of the Hospital Dr. Julio C. Perrando in Resistencia, Argentina.

Patients that denied participating, with a history of gastric endoscopy, who had received antibiotics, proton pump inhibitors, histamine receptors antagonists or bismuth compounds in the last four weeks, were excluded.

The selection of patients was non-probabilistic and intentional type. The size of sample was defined on base to the total number of patients annually attending to the Service of Gastroenterology and the prevalence of $H$. pylori in patients suffering dyspepsia according data from literature.

The institutional Bioethical Committee approved all procedures and those patients that accepted to participate provided a written informed consent prior to sampling. Demographic, epidemiological, and clinical data were recorded.

Without oral hygiene, dental plaque and saliva, were sampled. All samples were stored at $-20^{\circ} \mathrm{C}$ until their further processing by molecular methods.

After oral clinical examination and collection of the oral samples, the patients were subjected to UGVE examination. UGVE has carried out using an endoscope OlimpusRCV-100 GIF-130. Two gastric samples were taken at 2 or $3 \mathrm{~cm}$ from the pylorus and were stored at $-20^{\circ} \mathrm{C}$ to further processing.

DNA was isolated from all samples using the CTAB method and was immediately subjected to conventional PCR.

Purified DNA was carried out for detection of $H$. pylori by conventional PCR using primers derived from the ure A gene ${ }^{(18) .}$

In the samples positives for $H$. pylori, the virulence markers were studied, amplifying the $\operatorname{cag} A$ and $b a b A 2$ genes according to the protocols previously published ${ }^{(8)}$.

In all protocols, positive and negative controls supplied by a colleague from the University of Concepción (Chile) were included.

\section{RESULTS}

During the period of study, 61 dyspeptic patients with digestive diseases and indication for UGVE were selected, 30 females and 31 males. Patients ranged in age from 18 to 69 years (Average 45 years).

H. pylori was detected in 31/61 gastric samples and in 31/61 oral samples (Figure 1), indicating a prevalence of $50.8 \%$ in both body sites.

Due to insufficient quantity or bad quality of DNA obtained, genotyping was performed in 31 positive gastric samples but only in 16 dental plaques and 1 saliva sample (Figure 2).

Table 1 shows the correlation between different genotypes of $H$. pylori in the studied samples. As it was expected, the vacA gene was detected in $100 \%$ of oral and gastric samples. The $\operatorname{cag} A+$ was significantly more frequent in gastric biopsies tan in oral cavity.

In 12/31 (38.7\%) patients concordance between the genotypes found in their oral and gastric samples was found.

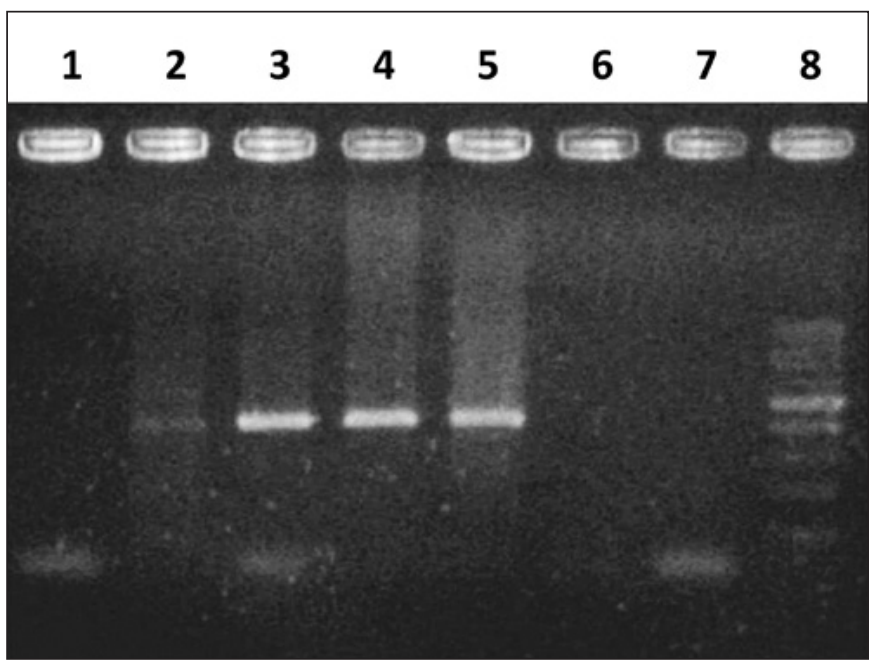

FIGURE 1. Agarose gel electrophoresis of $H$. pylori detection in gastric samples. Lines 2 to 5: positive samples. The molecular weight of the amplicon corresponding to the ureA gene is $411 \mathrm{bp}$. Line 8: $100 \mathrm{bp}$ weight marker.

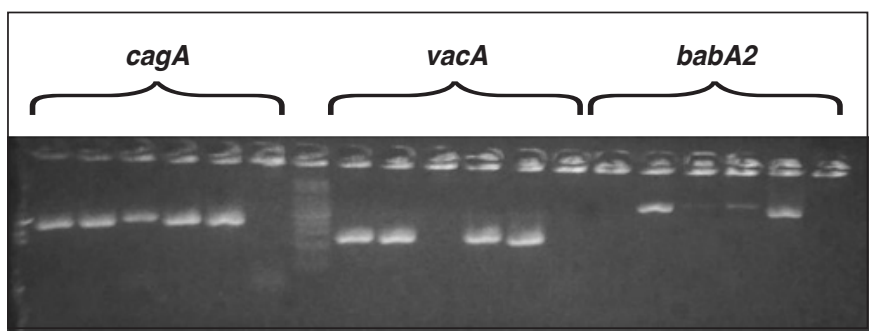

FIGURE 2. Agarose gel electrophoresis of $H$. pylori genotyping products in gastric samples. The molecular weights of the different amplicons are: cagA $400 \mathrm{bp}$, vacA 259 and babA2 $831 \mathrm{bp}$. Line 7: $100 \mathrm{bp}$ weight marker.

TABLE 1. Distribution of genotypes among different samples

\begin{tabular}{lcc}
\hline Genotypes & Biopsies $(\mathrm{n}=31)$ & Oral $(\mathrm{n}=17)$ \\
\hline $\operatorname{vac} A$ & $31(100 \%)$ & $17(100 \%)$ \\
$\operatorname{cag} A$ & $22(71 \%)$ & $5(29 \%)$ \\
babA2 & $3(9.7 \%)$ & $3(17.6 \%)$ \\
\hline
\end{tabular}

Table 2 and Table 3 show the distribution of genotypes according the different oral and gastroduodenal diseases. No significant differences were found among pathological groups regarding the genotypes studied $(P$ value $>0.05)$.

TABLE 2. Relationship between genotypes and digestive diseases

\begin{tabular}{lccccc}
\hline & \multicolumn{5}{c}{ Gastroduodenal diseases } \\
\cline { 2 - 6 } Genotypes & $\begin{array}{c}\text { ACG } \\
\mathbf{n}=\mathbf{1 8}\end{array}$ & $\begin{array}{c}\text { ACGFM } \\
\mathbf{n}=\mathbf{8}\end{array}$ & $\begin{array}{c}\text { CGND } \\
\mathbf{n}=5\end{array}$ & $\begin{array}{c}\text { Total } \\
\mathbf{n}=31\end{array}$ & $\boldsymbol{P}$ value \\
\hline vacA & 18 & 8 & 5 & 31 & \\
$\operatorname{cag} A$ & 13 & 4 & 5 & 22 & 0.25 \\
babA2 & 2 & 0 & 1 & 3 & 0.60 \\
\hline
\end{tabular}

ACG: H. pylori associated active chronic gastritis; ACGFM: H. pylori associated active chronic gastritis with focus of metaplasia; CGND: chronic gastritis with non-specific duodenitis. 
TABLE 3. Relationship between genotypes and oral status

\begin{tabular}{lccccc}
\hline & \multicolumn{6}{c}{ Oral status } \\
\cline { 2 - 6 } Genotypes & $\begin{array}{c}\text { Gingivitis } \\
\mathbf{n}=10\end{array}$ & $\begin{array}{c}\text { Periodontitis } \\
\mathbf{n}=5\end{array}$ & $\begin{array}{c}\text { Normal } \\
\mathbf{n}=2\end{array}$ & $\begin{array}{c}\text { Total } \\
\mathbf{n}=17\end{array}$ & $\boldsymbol{P}$ value \\
\hline vacA & 10 & 5 & 2 & 17 & - \\
$\operatorname{cag} A$ & 2 & 0 & 2 & 5 & 0.25 \\
babA2 & 0 & 2 & 1 & 3 & 0.60 \\
\hline
\end{tabular}

\section{DISCUSSION}

It has become increasingly clear that populations in humans are highly diverse and this heterogeneity can be analyzed at two different levels: genotypic variation among strains and variations in $H$. pylori populations within an individual host ${ }^{(5)}$.

The presence of multiple organisms within a host may occur as a result of recombination events leading to genetic shift, whereas ongoing mutation within a strain can lead to the formation of quasispecies by genetic drift ${ }^{(5)}$.

In the oral cavity there exists a live $H$. pylori that has negative influences on the eradication of stomach infection and as long as physicians agree with the idea of a second colonized site within the oral cavity, the rate for successful eradication of $H$. pylori will increase ${ }^{(39)}$.

From 1989 to date, many researchers worldwide have identified H. pylori in plaque and saliva with varying results ${ }^{(1)}$.

H. pylori was found in saliva of $33(42.3 \%)$ patients and in dental plaque samples of $37(47.4 \%)$ patients ${ }^{(38)}$. In dental plaque $60 \%$ of the patients with chronic periodontitis were found to be positive for $H$. pylori ${ }^{(2)}$. In the present work, H. pylori was detected in $50.8 \%$ of oral samples.

The $H$. pylori DNA was found with variable frequencies in gastric samples from patients suffering gastroduodenal disorders, ranging from 48 to $63 \% 0^{(17,25,27)}$.

The percentages of positivity for $H$. pylori in gastric samples were lower than previously found in symptomatic patients in Argentina. Medina et al. reported $88.3 \%$ of positivity in gastric samples in patients suffering digestive pathologies ${ }^{(19)}$, meanwhile Jimenez et al. published $91 \%$ of $H$. pylori- positive gastric samples ${ }^{(11)}$.

Not always $H$. pylor $i$ is found simultaneously in oral cavity and in gastric samples. Román-Román et al. found $H$. pylori DNA in saliva and in biopsy in $24 \%$ of patients, $52.5 \%$ were saliva negative/ biopsy positive and $6.6 \%$ were saliva positive/biopsy negative ${ }^{(31)}$.

Berroteran et al. investigated $H$. pylori presence in dental plaque from dyspeptic patients ${ }^{(4)}$. They found that $75 \%$ of patients presented $H$. pylori-positive gastric pathology, and 38\% presented $H$. pylori in the dental plaque, assuming this organism in the dental plaque could be a risk factor for gastrointestinal reinfection.

As published for Trevizani Rasmussen et al., of the 66 patients who were $H$. pylori positive in their gastric biopsies, $19(28.8 \%)$ were found not to have $H$. pylori in the oral cavity. In other hand, of the 12 patients whose gastric biopsies were negative for $H$. pylori, six $(50 \%)$ were found not to have $H$. pylori in the oral cavity ${ }^{(38)}$.

In gastric biopsies, it was found a higher prevalence than reported by other authors.

The prevalence of $\operatorname{cag} A$ gene was $48.7 \%$ among the positive samples and was not significantly associated with the gastroduodenal diseases ${ }^{(17)}$. Among patients with chronic gastritis, 39.2\% were $\operatorname{cag} A+{ }^{(27)}$. The $\operatorname{cag} A$ gene was detected in $42(56.0 \%)$ strains in Cuban patients with upper gastrointestinal diseases ${ }^{(10)}$.
In one study the prevalence of $\operatorname{cag} A$ gene was $48.7 \%$, lower than other reports in African countries ${ }^{(17)}$ and was present in $73.3 \%$ of isolates ${ }^{(6)}$

In patient positives for $H$. pylori in gastric biopsies, the $\operatorname{cag} A$ gene was detected in $43.3 \%$ of gastric biopsies, in $43.8 \%$ of saliva samples, and in $27.3 \%$ of dental plaque samples, noting that dental plaque and saliva can serve as temporary storage for the $\operatorname{cag} A$ variant $H$. pylori in individuals with gastric disease ${ }^{(34)}$. In other study, the $\operatorname{cag} A$ gene was present in gastric biopsies from $84 \%$ of patients with gastroduodenal disorders ${ }^{(25)}$.

In saliva samples and in dental plaque the prevalence of $\operatorname{cag} A$ gene found in the present work was like that reported previously. The $\operatorname{cag} A$ gene was found in $27(45 \%)$ of the 60 samples of $H$. pylori-positive saliva samples ${ }^{(28)}$. In a previous study, 14 from 18 patients harbored the $\operatorname{cag} A+$ genotype of $H$. pylori, but only 9 of them presented this genotype in stomach ${ }^{(33)}$. These studies suggest that the genotyping must be performed simultaneously in oral cavity and in stomach.

Some authors, in agreement with the findings here presented, reported about a low correlation between the gastric infection and the presence of $\operatorname{cag} A+$ genotype in oral cavity ${ }^{(31)}$.

Although there are several genes associated with adhesion of the bacteria, the $b a b A 2$ gene is associated with successful colonization $^{(21)}$.

In the present work, the $b a b A 2+$ genotype was the less frequent, in agreement with previous reports. In patients with chronic gastritis $^{(12)}$. Nevertheless, a recent study reported that babA2 prevalence was significantly higher in gastric biopsies obtained from chronic gastritis patients $(95 \%)$ when compared with duodenal ulcer patients $(18.1 \%)$ and non-ulcer dyspepsia subjects $(26.1 \%)^{(30)}$.

Arévalo et al. found that $57 \%$ of the gastric isolates were babA2+(3), which coincides with other South American studies that reported gene frequencies ranging from $40.4 \%$ to $82.3 \%$ in stomach samples ${ }^{(16,27,29,37)}$.

When $b a b A 2$ and $\operatorname{cag} A$ are coexpressed in the same $H$. pylori strain, they work synergistically in worsening inflammation and may be a potential risk of intestinal metaplasia ${ }^{(30)}$.

Taking into account the genes association, it was found the $\operatorname{cag} A+/ b a b A 2+$ combination in $9.7 \%$ of gastric biopsies and in $17.6 \%$ of oral samples. Similarly, this association was observed in $13.3 \%$ of gastric samples from patients suffering chronic gastritis as reported by Paniagua et al. ${ }^{(27)}$. Regarding the coincidence between the same genotype in oral cavity and gastric mucosa, the genotypes found in saliva and biopsy of the same patient had $51.1 \%$ agreement ${ }^{(31)}$. Other studies show that people can be infected simultaneously by two or more genotypes of $H$. pylori ${ }^{(22)}$, due to coinfection or genetic variation ${ }^{(24)}$. In the present work the same genotypes were found simultaneously in oral and gastric samples from the same patient in $38.7 \%$ of them. However, complete genomes of the detected strains should be sequenced, since this is the only way to demonstrate genetic identity.

Nevertheless, as published previously, we did not find a statistical correlation between the virulence genes and the gastroduodenal or oral diseases ${ }^{(17,36)}$. That could be due to the small number of patients with $H$. pylori harboring each virulence marker.

Additionally, further studies may be performed to correlate different digestive disorders with the presence of various virulence factors, including the iceA protein and the different alleles of $\operatorname{vac} A$ gen $^{(10)}$. 


\section{CONCLUSION}

This study is the first in provide information about the genotypes of the Argentinean Northeast $H$. pylori strains. Despite the high prevalence of $H$. pylori infection, the most of patients had less virulent genotypes in oral cavity and gastric tissue. The cagAl $b a b A 2$ combination was not frequent in the samples studied. There was not a statistical correlation between the virulence genes and gastroduodenal or oral diseases.

Although in some patients the same genotype was found both in oral and gastric samples, it cannot be ensure that they corresponding to the same strain because a DNA sequencing was not performed.

\section{ACKNOWLEDGMENTS}

To Dr. Apolinaria García Cancino (University of Concepción, Chile) for suppling the control strains and to the Staff of the Histocompatibility and Genetic Laboratory of the Hospital "Dr. Julio C. Perrando" (Resistencia, Argentina) for helping in genes detection.

\section{Authors' contributions}

Medina ML: samples and data collection, survey execution, revision of text. Medina MG: survey execution, statistical analysis, revision of text. Merino LA: samples processing, survey execution, writing of text.

Medina ML, Medina MG, Merino LA. Correlação entre marcadores de virulência de Helicobacter pylori na cavidade oral e em biópsias gástricas. Arq Gastroenterol. 2017;54(3):217-21.

RESUMO - Contexto - O resultado clínico da infecção por Helicobacter pylori tem sido associado com fatores de virulência. A presença desses fatores como marcadores moleculares é útil na identificação do risco elevado para o desenvolvimento de graves patologias gástricas. Objetivos - Correlacionar a presença de marcadores de virulência $c a g A$ e bab2 A do H. pylori em amostras de biópsias gástricas e orais. Métodos - Um estudo observacional, prospectivo, descritivo e transversal foi realizado entre setembro de 2011 e setembro de 2012. Foram incluídos pacientes com sintomas de dispepsia com indicação de endoscopia gastrointestinal que compareceram ao Serviço de Gastroenterologia do Hospital Dr. Julio C. Perrando. Investigação epidemiológica foi concluída. Para detectar a bactéria e seus genes de virulência, amostras de saliva, placa dentária e biópsia gástrica foram tomadas e processadas pelo PCR. Resultados - Sessenta e um pacientes foram selecionados para este estudo ( 30 mulheres e 31 homens). H. pylori foi detectado em 31 biópsias gástricas e 31 amostras orais. Foi encontrada diferença significativa entre as amostras orais e gástricas no genótipo cag $A$. A ocorrência simultânea entre genótipos orais e gástricos do mesmo paciente foi encontrada em 38,7\% das amostras. Conclusão - Este é o primeiro estudo a fornecer informações sobre os genótipos das cepas do H. pylori no Nordeste Argentino. Apesar da alta prevalência da infecção pelo H. pylori, a maioria dos pacientes tinha genótipos menos virulentos na cavidade oral e tecido gástrico. A combinação cag A/babA2 não foi frequente nas amostras estudadas. Não houve correlação estatística entre os genes de virulência e doenças gastroduodenais ou orais. Embora em alguns pacientes o mesmo genótipo tenha sido encontrado tanto nas amostras orais quanto gástricas, não se pode garantir que correspondam à mesma variação, pois um sequenciamento de DNA não foi realizado.

DESCRITORES - Helicobacter pylori, genética. Infecções por Helicobacter, diagnóstico. Mucosa gástrica, microbiologia. Saliva, microbiologia.

\section{REFERENCES}

1. Adler I, Muiño A, Aguas S, Harada L, Diaz M, Lence A, et al. Helicobacter pylori and oral pathology: relationship with the gastric infection. World J Gastroenterol. 2014;20:9922-35.

2. Agarwal S, Jithendra K. Presence of Helicobacter pylori in subgingival plaque of periodontitis patients with and without dyspepsia, detected by polymerase chain reaction and culture. J Indian Soc Periodontol. 2012;16:398-403.

3. Arévalo Galvis A, Trespalacios Rangel A, Otero W, Mercado Reyes M, Poutou Piñales R. Prevalence of $c a g A, v a c A, b a b A 2$ and ice A genes in H. pylori strains isolated from Colombian patients with functional dyspepsia. Polish J Microbiol. 2012;61:33-40.

4. Berroterán A, Perrone M, Correnti M, Cavazza M, Tombazzi C, Gonçalvez R Prevalencia de Helicobacter pylori en muestras de placa dental de un grupo de pacientes venezolanos mediante la técnica de reacción en cadena de la polimerasa. Acta Odontol Venez. 2002;40:45-51.

5. Blaser MJ. Heterogeneity of Helicobacter pylori. Eur J Gastroenterol Hepatol. 2012;9 (Suppl 1):S3-6-7.

6. Breurec S, Michel R, Seck A, Brisse S, Côme D, Dieye FB, et al. Clinical relevance of $\operatorname{cag} A$ and $v a c A$ gene polymorphisms in Helicobacter pylori isolates from Senegalese patients. Clin Microbiol Infect. 2012;18:153-9.

7. Castillo-Rojas G, Mazarí-Hiriart M, López-Vidal Y. Helicobacter pylori: Focus on CagA and VacA major virulence factors. Salud Pub Mex. 2004;46:538-48.

8. Chomvarin C, Namwat W, Chaicumpar K, Mairiang P, Sangchan A, Sripa B, et al. Prevalence of Helicobacter pylori vacA, cagA, cagE, ice A and babA2 genotypes in Thai dyspeptic patients. Int J Infect Dis. 2008;12:30-6.

9. Conteduca V, Sansonno D, Lauletta G, Russi S, Ingravallo G, Dammacco F. H pylori infection and gastric cancer: state of the art. Int J Oncol. 2013;42:5-18.

10. Feliciano O, Gutierrez O, Valdés L, Fragoso T, Calderin AM, Valdes AE, et al. Prevalence of Helicobacter pylori vacA, $\operatorname{cag} A$, and ice $A$ genotypes in Cuban patients with upper gastrointestinal diseases. Biomed Res Int. 2015;2015:1-6.
11. Jimenez F, Barbaglia Y, Bucci P, Tedeschi F, Zalazar F. Detección molecular y genotipificación de Helicobacter pylori en biopsias gástricas de pacientes adultos sintomáticos de la ciudad de Santa Fé, Argentina. Rev Argent Microbiol 2013;45:39-43.

12. Jin S, Heo S, Jeon A, Chang H, Lee H, Park K, et al. Detection of Helicobacter pylori and BabA (Blood-group Antigen Binding Adhesin) in saliva and gastric tissue by Polymerase Chain Reaction. J Lab Med Qual Assur. 2004; $26: 243-8$.

13. Jones K, Whitmire J, Merrell D. A tale of two toxins: Helicobacter pylori CagA and VacA modulate host pathways that impact disease. Front Microbiol. 2010;1:1-17.

14. Kalali B, Mejías-Luque R, Javaheri A, Gerhard M. H. pylori virulence factors: influence on immune system and pathology. Mediators Inflamm. 2014;2014:1-9.

15. Khamri W, Walker M, Clark P, Atherton J, Thursz M, Bamford K, et al. Helicobacter pylori stimulates dendritic cells to induce Interleukin-17 expression from CD4+ T lymphocytes. Infect Immun. 2010;78:845-53.

16. Lobo Gatti L, Proença Módena J, Marques Payão S, Cardoso Smith M, Fukuhara Y, Pimenta Módena J, et al. Prevalence of Helicobacter pylori cagA, iceA and $b a b A 2$ alleles in Brazilian patients with upper gastrointestinal diseases. Acta Trop. 2006; 100:232-40.

17. M'itonga L, Kimang'a A, Ngugi C, Mutie T. Association of Helicobacter pylor $v a c A$ gene polymorphisms and $\operatorname{cag} A$ gene with clinical outcome in dyspeptic patients. Int J Heal Sci Res. 2015;5:436-44.

18. Medina M, Medina M, Lösch L, Merino L. Detección de Helicobacter pylori en muestras clínicas y agua mediante PCR. In: Merino LA, Giusiano GE, editors Manual de Métodos Moleculares para Estudios Microbiológicos. 1st ed. Buenos Aires: Asociación Argentina de Microbiología; 2011. Pp. 207-8.

19. Medina M, Medina M, Martín G, Picón S, Bancalari A, Merino L. Molecular detection of Helicobacter pylori in oral samples from patients suffering digestive pathologies. Med Oral Patol Oral Cir Bucal. 2010;15:e38-42. 
20. Mehmood A, Akram M, Ahmed A, Usmanghani K, Hannan A, Mohiuddin E, et al. Helicobacter pylori: an introduction. Int J Appl Biol Pharm Technol. 2010;1:1337-51.

21. Menezes da Costa D, dos Santos Pereira E, Barem Rabenhorst S. What exists beyond cag A and vacA Helicobacter pylori genes in gastric diseases?. World J Gastroenterol. 2015;21:10563-72.

22. Momtaz H, Souod N, Dabiri H. Comparison of the virulence factors of Helicobacter pylori isolated in stomach and saliva in Iran. Am J Med Sci. 2010;340:345-9.

23. Murata-Kamiya N. Pathophysiological functions of the CagA oncoprotein during infection by Helicobacter pylori. Microbes Infect. Elsevier Masson SAS 2011;13:799-807.

24. Occhialini A, Urdaci M, Doucet-Populaire F, Bébéar C, Lamouliatte H, Mégraud F. Macrolide resistance in Helicobacter pylori: rapid detection of point mutations and assays of macrolide binding to ribosomes. Antimicrob Agents Chemother. 1997;41:2724-8.

25. Pajavand H, Alvandi A, Mohajeri P, Bakhtyari S, Kalali B, Gerhard M, et al. High Frequency of vacAs $1 \mathrm{~m} 2$ Genotypes Among Helicobacter pylori Isolates From Patients With Gastroduodenal Disorders in Kermanshah, Iran. Jundishapur J Microbiol. 2015;8:e25425.

26. Palframan S, Kwok T, Gabriel K, Cover T. Vacuolating cytotoxin A (VacA), a key toxin for Helicobacter pylori pathogenesis. Front Cell Infect Microbiol. 2012;2:1-9.

27. Paniagua GL, Monroy E, Rodríguez R, Arroniz S, Rodríguez C, Cortéz FL, et al. Frequency of $\operatorname{vac} A, \operatorname{cag} A$ and $b a b A 2$ virulence markers in Helicobacter pylor strains isolated from Mexican patients with chronic gastritis. Ann Clin Microbiol Antimicrob. 2009;8:1-6.

28. Paniagua-Contreras G, Monroy-Perez E, Alcántara-Carmona M, GarcíaGonzález O, Vaca-Pacheco S. Prevalencia de Helicobacter pylori y de los genotipos vacA y $\operatorname{cag} A$ en la saliva de pacientes con gastritis. Rev Med Hosp Gen Mex. 2007;70:107-14.

29. Quiroga J, Cittelly D, Bravo M. Helicobacter pylori en pacientes colombianos con enfermedades gastroduodenales. Biomédica. 2005;25:325-34

30. Roesler BM, Rabelo-Gonçalves EMA, Zeitune JMR. Virulence Factors of Helicobacter pylori: A review. Clin Med Insights Gastroenterol. 2014;7:9-17.
31. Román-Román A, Giono-Cerezo S, Camorlinga-Ponce M, Martínez-Carrillo D, Loaiza-Loeza S, Fernández-Tilapa G. vacA genotypes of Helicobacter pylori in the oral cavity and stomach of patients with chronic gastritis and gastric ulcer. Enferm Infecc Microbiol Clin. 2013;31:130-5.

32. Sayehmiri F, Kiani F, Sayehmiri K, Soroush S, Asadollahi K, Alikhani M, et al. Prevalence of $\operatorname{cag} A$ and $\operatorname{vac} A$ among Helicobacter pylori-infected patients in Iran: a systematic review and meta-analysis. J Infect Dev Ctries. 2015;9: 686-96.

33. Sepúlveda E, Moreno J, Spencer M, Quilodrán S, Brethauer U, Briceño C. Comparación de Helicobacter pylori en cavidad oral y mucosa gástrica de acuerdo a genotipo de virulencia (cagA y vacAm1). Rev Chil Infectol. 2012;29: $278-83$.

34. Silva D, Stevens R, Macedo J, Albano R, Falabella M, Fischer R, et al. Presence of Helicobacter pylori in supragingival dental plaque of individuals with periodontal disease and upper gastric diseases. Arch Oral Biol. 2010;55:896-901.

35. Silva D, Stevens R, Macedo J, Albano R, Falabella M, Veerman E, et al. Detection of cytotoxin genotypes of Helicobacter pylori in stomach, saliva and dental plaque. Arch Oral Biol. 2009;54:684-8

36. Tanih N, McMillan M, Naidoo N, Ndip L, Weaver L, Ndip R. Prevalence of Helicobacter pylori vacA, cag $A$ and ice $A$ genotypes in South African patients with upper gastrointestinal diseases. Acta Trop. 2010;116:68-73.

37. Torres L, Melián K, Moreno A, Alonso J, Sabatier C, Hernández M, et al. Prevalence of $v a c A, \operatorname{cag} A$ and $b a b A 2$ genes in Cuban Helicobacter pylori isolates. World J Gastroenterol. 2009;15:204-10.

38. Trevizani Rasmussen L, de Labio RW, Lobo Gatti L, da Silva LC, Fagundes de Queiroz V, de Arruda Cardoso Smith M, et al. Helicobacter pylori detection in gastric biopsies, saliva and dental plaque of Brazilian dyspeptic patients. Mem Inst Oswaldo Cruz. 2010;105:326-30.

39. Yee J. Helicobacter pylori colonization of the oral cavity: A milestone discovery. World J Gastroenterol. 2016;22:641-8.

40. Yu J, Leung W, Go M, Cjhan M, To K, Ng E, et al. Relationship between Helicobacter pylori babA2 status with gastric epithelial cell turnover and premalignant gastric lesions. Gut. 2002;51:480-4. 